\title{
Dampak Pemutihan Karang Keras pada Komunitas Ikan Karang dan Makrozoobenthos di Wilayah Perairan Tejakula, Buleleng, Bali
}

\author{
Elok Faiqoh'1), I Wayan Gede Astawa Karang, Dwi Budi Wiyanto \\ Prodi Ilmu Kelautan, Fakultas Kelautan dan Perikanan, Universitas Udayana \\ 1)elokfaiqoh@unud.ac.id
}

DOI: http://dx.doi.org/10.21107/rekayasa.v12i1.5290

\begin{abstract}
ABSTRAK
Pemutihan karang merupakan salah satu dampak dari perubahan iklim global, kenaikan suhu tersebut memberikan dampak negatif bagi keseimbangan ekosistem terumbu karang. Terumbu karang yang memutih dan kehilangan zooxanthella nya akan rentan terkena infeksi dan penyakit. Populasi komunitas ikan karang pemakan hewan karang dan makrozoobenthos juga akan menurun. Tujuan dari penelitian ini adalah untuk mengetahui besar dampak kerusakan terumbu karang dan dampaknya bagi populasi ikan dan makrozoobenthos. Survey dilakukan pada 3 titik di wilayah perairan Tejakula dengan metode reefcheck. Hasil penelitian menunjukkan kematian terumbu karang sebesar 5-7.5\%, jumlah alga yang menutupi $3.125 \%$. Kondisi ikan kepe-kepe yang merupakan pemakan hewan karang juga sudah ditemukan dalam jumlah cukup banyak. Keberadaan ikan herbivora dan makrozoobenthos herbivore membantu mengurangi jumlah alga yang menutupi. Sedangkan keberadaan ikan pemakan terumbu karang dan ikan predator memperlihatkan bahwa sistem ekologi yang ada di terumbu karang tersebut hampir kembali normal.
\end{abstract}

Kata Kunci: terumbu karang, komunitas ikan karang, makrozoobenthos.

\section{The Impact of Hard Coral Bleaching in Coral and Macrozoobenthos Fish Communities in Tejakula, Buleleng, Bali Water Areas}

\begin{abstract}
Coral bleaching is one of the consequences of global climate change, as the rise of temperature negatively impacts the ecological balance of reef ecosystems. Bleached coral reefs lose their zooxanthellae, increasing vulnerability to infection and disease and consequently, causing population decline of macrozoobenthos and reef fish communities which prey on coral-consuming organisms. This research aims to determine the degree of coral reef damage and its impact on fish and macrozoobenthos population. The survey was conducted on 3 stations in Tejakula waters with the reef check method. Results show that coral reef death reaches 5-7.5\%, with algal coverage of $3.125 \%$. Kepe-kepe fish which prey on coral-consuming animals were also found in relatively high abundance. The presence of herbivore fish and macrozoobenthos help reduce algal cover. Meanwhile, the presence of coral-consuming and predator fish indicate that the coral reef ecological system has mostly returned to normal.
\end{abstract}

Keywords: coral reef, reef fish community, macrozoobenthos

\section{PENDAHULUAN}

Kenaikan suhu bumi merupakan salah satu indikasi terjadinya perubahan iklim secara global. Perubahan suhu 1 dekade menunjukkan perubahan yang signifikan yaitu rata-

\section{Article History:}

Received: Maret 2019; Accepted: April 2019

ISSN: 2502-5325 (Online) Terakreditasi Peringkat 4 oleh

Kementerian Riset, Teknologi dan Pendidikan Tinggi (ARJUNA),

berdasarkan Keputusan Direktur Jenderal Penguatan Riset dan

Pengembangan Nomor: 21/E/KPT/2018 tanggal 9 Juli 2018 rata sebesar $0.2^{\circ} \mathrm{C}$ (Strong, et.al, 2008). Peningkatan ini diduga akan terus terjadi dan untuk beberapa wilayah akan mengalami peningkatan yang lebih cepat dibandingkan dengan wilayah lain. Perubahan suhu akan mempengaruhi ekosistem yang ada di laut.

\footnotetext{
Cite this as:

Faiqoh, E., Karang, I., \& Wiyanto, D. (2019). Dampak Pemutihan Karang Keras pada Komunitas Ikan Karang dan Makrozoobenthos di Wilayah Perairan Tejakula, Buleleng, Bali. Rekayasa, 12(1), 24-29. doi:http://dx.doi.org/10.21107/rekayasa.v12i1.5290 (C) 2019 Universitas Trunojoyo Madura
} 
Salah satunya ekosistem terumbu karang.

Terumbu karang Indonesia memiliki luasan sebesar 2.5 juta hektar dengan tingkat keanekaragaman jenis karang dan ikan yang tinggi, juga hewan dasarnya. Kenaikan suhu laut memberikan dampak yang signifikan bagi terumbu karang Indonesia. Fenomena pemutihan karang akibat naiknya suhu permukaan laut, terjadi di seluruh wilayah Indonesia pada tahun 2016 lalu. 16 wilayah Indonesia melaporkan adanya kejadian pemutihan karang di sekitar perairannya (Reefcheck.or.id, 2017).

Bali wilayah yang terletak di tengah Indonesia, merupakan salah satu wilayah yang melaporkan terjadinya pemutihan karang. Dalam buku status terumbu karang Indonesia yang dirilis oleh Lembaga Penelitian Indonesia Tahun 2017, dikatakan bahwa dari 25 stasiun sample pengambilan data terumbu karang, 19 stasiun termasuk dalam kategori jelek. Daerah terumbu karang yang paling luas terkena pemutihan karang adalah perairan kecamatan Tejakula. Persentase karang yang terkena pemutihan karang di setiap tempat survey pemutihan karang adalah sebesar lebih dari 25 \% (Reefcheck, 2016) dengan tingkat kematian yang tinggi pada terumbu karang hasil transplantasi.

Pemutihan karang akan memberikan dampak bagi keseimbangan ekosistem terumbu karang. Terumbu karang akan menjadi putih disebabkan karena suhu udara yang meningkat akan memicu zooxanthella (alga yang bersimbiosis dengan polip karang dan pemberi warna pada karang) memproduksi senyawa kimia berbahaya bagi polip karang (Jones et al. 1998, Hoegh-Guldberg \& Jones 1999), sehingga polip karang akan mengeluarkan zooxanthella dari tubuhnya. Terumbu karang yang kehilangan zooxanthella nya akan rentan terkena infeksi dan penyakit (Rani, 2001). Selain itu, terumbu karang yang kehilangan zooxanthella, akan mengalami penurunan pertumbuhan, sehingga lebih mudah kehilangan ruang akibat rendahnya kemampuan kompetisi dengan organisme lain. Terumbu karang yang mengalami pemutihan akan dengan cepat ditutupi alga bentik (Mumby, et.al, 2007).

Dampak lain pemutihan karang, bukan hanya pada terumbu karangnya itu sendiri, tetapi dapat terjadi pada komunitas yang tinggal di ekosistem terumbu karang, seperti ikan. Pada komunitas ikan karang pemakan hewan karang, akan kehilangan makanan mereka dan lama kelamaan akan berdampak pada penurunan populasi ikan pemakan karang (Muttaqin, et.al, 2014).

Dampak dan pengaruh pemutihan karang bisa terjadi secara langsung, bila kita lihat dari biota karang itu sendiri dan juga bisa terjadi secara tidak langsung, bila kita lihat pada biota yang bergantung pada terumbu karang. Monitoring dan penelitian berkesinambungan dapat menolong ekosistem terumbu karang dari kerusakan lebih lanjut dan dapat mempermudah pemerintah daerah untuk membuat rencana 'pengelolaan ekosistem terumbu karang di daerah pencadangan konservasi. Perhitungan penutupan karang dan kelimpahan dari kategori kesehatan karang. Perhitungan penutupan karang diketahui dengan persamaan berikut menurut English et al. (1997). Untuk mengetahui kategori persen tutupan karang hidup dengan pengkategorian menurut Keputusan Menteri Lingkungan Hidup No.4 Tahun 2001 tentang Kriteria Baku Kerusakan Terumbu Karang sebagai berikut:

Penelitian ini dilakukan untuk mengetahui kondisi terumbu karang yang ada di wilayah perairan Tejakula yang sempat mengalami pemutihan karang pada tahun 2016 yang merupakan bencana global di Indonesia.

\section{METODE PENELITIAN}

Penelitian ini dilakukan di perairan kecamatan Tejakula Buleleng, Bali Utara. Survei dilakukan pada tiga titik di wilayah tersebut. Penelitian ini dilakukan pada bulan April-Mei 2018. Peta lokasi penelitian dapat dilihat pada Gambar 1. Metode pengambilan data yang digunakan adalah metode reefcheck, di mana terdapat empat kategori data: (1) data substrat; (2) data ikan (target dan indikator); (3) data invertebrata; dan (4) data penyakit karang, pemutihan, dan sampah pada karang.

\section{Pengamatan substrat dan karang}

Substrat yang dimaksud merupakan jenis terumbu karang yang hidup di situs penelitian dan substrat tempatnya menempel. Jenis terumbu karang didata berdasarkan bentuk pertumbuhannya.

Garis substrat diamati dengan metode transek point-intercept menggunakan pita transek dengan interval pengamatan setiap $0.5 \mathrm{~m}$. 


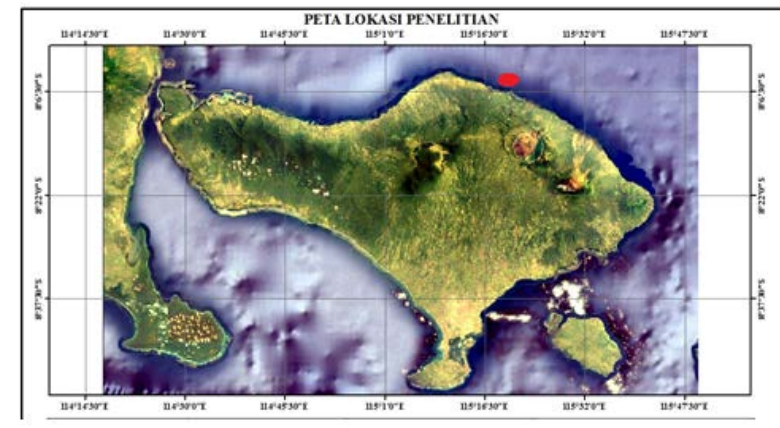

Gambar 1. Peta Lokasi Penelitian

\section{Komposisi jenis karang}

Komposisi jenis (KJ) karang dihitung dengan menggunakan persamaan di bawah ini:

$\mathrm{KJ}=\frac{n i n i}{N \mathrm{~N}} \times 100 \%$

Keterangan:

KJ : Komposisi jenis (\%)

ni : Jumlah individu setiap jenis

$\mathrm{N}$ : Jumlah individu seluruh jenis

\section{Pengamatan ikan karang dan invertebrata}

Pengamatan ikan karang dan invertebrata dilakukan dengan metode sensus visual menggunakan transek garis dengan pita transek sepanjang 20 meter dan lebar antara garis 5 meter. Data ikan yang diambil adalah ikan target penangkapan nelayan dan ikan indikator terumbu karang. Data invertebrata diambil merupakan invertebrata sasaran untuk konsumsi atau koleksi akuarium.

\section{Kelimpahan ikan karang dan invertebrata}

Kelimpahan ikan karang dihitung dengan menggunakan persamaan (English et al., 1994) dibawah ini :

$N=\frac{n i}{A}$

Keterangan :

$\mathrm{N}$ : Kelimpahan ikan (ind/m2)

ni : Jumlah individu ke-i

A : Luasan area $\left(\mathrm{m}^{2}\right)$

\section{Pengamatan penyakit/pemutihan karang dan sampah pada karang}

Data kondisi karang yang diambil meliputi luas karang yang berpenyakit, mengalami pemutihan serta yang tertutup sampah.

\section{Presentase tutupan karang}

Analisis data meliputi perhitungan penutupan karang dan kelimpahan dari kategori kesehatan karang. Perhitungan penutupan karang diketahui dengan persamaan berikut menurut English et al. (1997).

Persentase tutupan $=\frac{\text { Panjang kategori tutupan }(\mathrm{cm})}{\text { Panjang transek }(\mathrm{cm})} \times 100 \%$

Untuk mengetahui kategori persen tutupan karang hidup dengan pengkategorian menurut Keputusan Menteri Lingkungan Hidup No.4 Tahun 2001 tentang Kriteria Baku Kerusakan Terumbu Karang sebagai berikut:

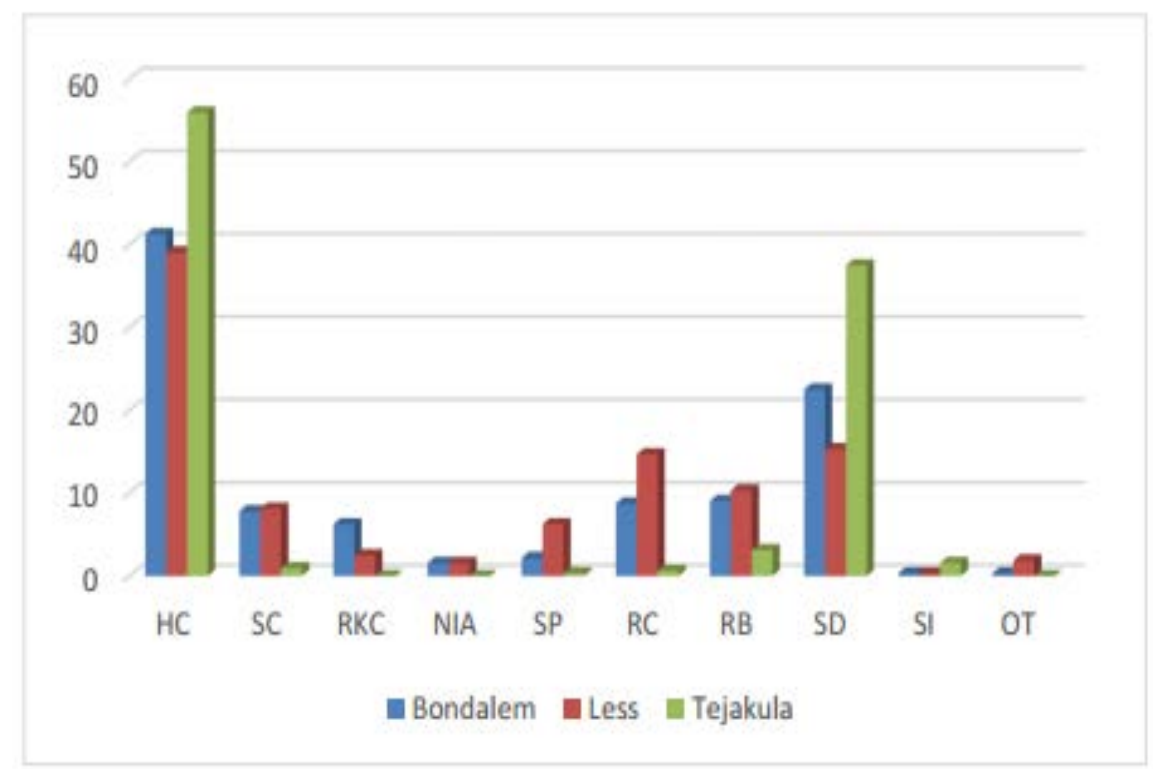

Gambar 2. Persentase tutupan karang kecematan Tejakula 
Tabel 1. Kriteria Baku Kerusakan Terumbu Karang

\begin{tabular}{|c|c|c|c|}
\hline Parameter & Kriteria Baku & $\begin{array}{l}\text { Kerusaka } \\
\text { rang(\%) }\end{array}$ & Imbu Ka- \\
\hline \multirow{4}{*}{$\begin{array}{l}\text { Presentase } \\
\text { Luas Tutupan } \\
\text { Terumbu } \\
\text { Karang } \\
\text { Hidup }\end{array}$} & \multirow{2}{*}{ Rusak } & Buruk & $0-24,9$ \\
\hline & & Sedang & $25-49,9$ \\
\hline & \multirow{2}{*}{ Baik } & Baik & $50-74,9$ \\
\hline & & Baik Sekali & $75-100$ \\
\hline
\end{tabular}

\section{HASIL DAN PEMBAHASAN}

Adapun hasil yang didapat dari penelitian yang telah dilakukan yaitu, tutupan karang keras (HC) hidup di kecamatan Tejakula cukup tinggi yaitu berkisar antara 55\%-39\% (gambar 2) yang terbesar ada di wilayah desa Tejakula yaitu sebesar $55.9 \%$. Substrat di perairan wilayah kecamatan Tejakula adalah pasir berbatu, dengan pasir yang lebih mendominasi. Hal tersebut terlihat dari persentase tutupan luasan yang hanya terdapat hamparan pasir lebih besar dibandingkan dengan batuan dan pecahan karang.

Jumlah rata-rata karang keras $(\mathrm{HC})$ yang terdapat di kecamatan Tejakula sebanyak 185 individu. Di wilayah perairan Tejakula didapatkan 9 jenis pertummbuhan yaitu Coral Massive (CM), Coral Submassive (CS), Coral Branching (CB), Acropora Tabulate (ACT), Coral Encrusting (CE), Acropora Branching (ACB), Coral Foliose (CF), Acropora Digitate (ACD) dan Mushroom (Msh) (gambar 3).

Wilayah Bondalem memiliki terumbu karang dengan jenis pertumbuhan yang lebih banyak yaitu 9 jenis, sedangkan wilayah Tejakula hanya sebanyak 7 jenis dan wilayah Less yang paling sedikit yaitu 5 jenis. Pertumbuhan jenis Coral Massive (CM) dan Coral Branching (CB) yang mendominasi. Persentase $\mathrm{CM}$ terbesar terdapat di wilayah Bondalem yaitu sebanyak 35 individu dan CB terbesar terdapat di

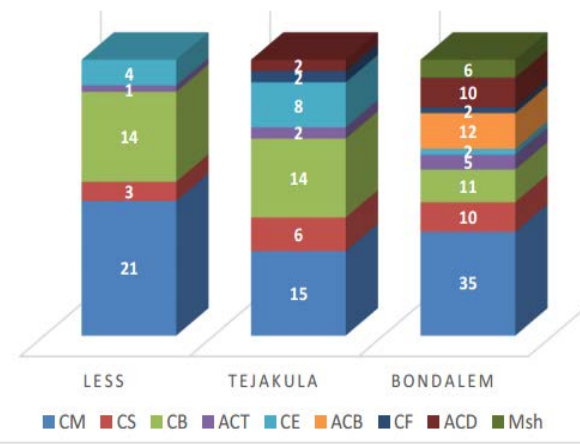

Gambar 3. Jumlah Hard Coral berdasarkan pertumbuhan wilayah Less dan Tejakula yaitu sebanyak 14 individu.

Perbandingan kondisi karang keras tahun 2016 (Reefcheck, 2016) dan kondisi terkini tahun 2018 diperlihatkan pada gambar 4. Dari gambar tersebut terlihat perubahan yang jelas terhadap kondisi terumbu karang. Pada tahun 2016 pemutihan karang bisa mencapai 45\% (di wilayah perairan Bondalem) dan kematian karang mencapai $39.53 \%$

Di wilayah perairan Less, namun pada tahun 2018, terumbu karang di daerah tersebut mengalami perbaikan dengan tidak ditemukannya lagi terumbu karang yang memutih dan terumbu karang mati tertinggi hanya berkisar 5\%-7.5\% yang ditemukan pada wilayah perairan Tejakula.

Dari hasil penelitian 9 ikan indikator yang di survei, hanya ditemukan 7 jenis ikan. Wilayah perairan Less dan Tejakula ditemukan 5 jenis ikan sedangkan wilayah perairan Bondalem lebih beragam yaitu 7 jenis ikan. Ikan kepekepe, ikan bibir tebal, ikan kakap dan ikan kakaktua selalu ditemukan di tiga perairan. Ikan bibir tebal dan ikan kepe-kepe didapatkan lebih banyak dari lainnya. Ikan bibir tebal di wilayah perairan Less dan Tejakula ditemukan lebih banyak daripada ikan kepe-kepe, namun pada wilayah perairan Bondalem terjadi sebaliknya. Sementara kerapu hanya ditemukan pada wilayah perairan Bondalem dan Less.

Kelimpahan ikan bibir tebal didapatkan tertinggi dari semua jenis ikan, yaitu sebesar 0.15 ind $/ \mathrm{m}^{2}$. Kelimpahan kerapu yang ditemukan di wilayah perairan Bondalem adalah sebesar $0.0088 \mathrm{ind} / \mathrm{m}^{2}$ dan di wilayah perairan Less $0.0013 \mathrm{ind} / \mathrm{m}^{2}$. Ukuran kerapu yang ditemukan didua perairan tersebut berkisar $30-40 \mathrm{~cm}$ (Tabel 2).

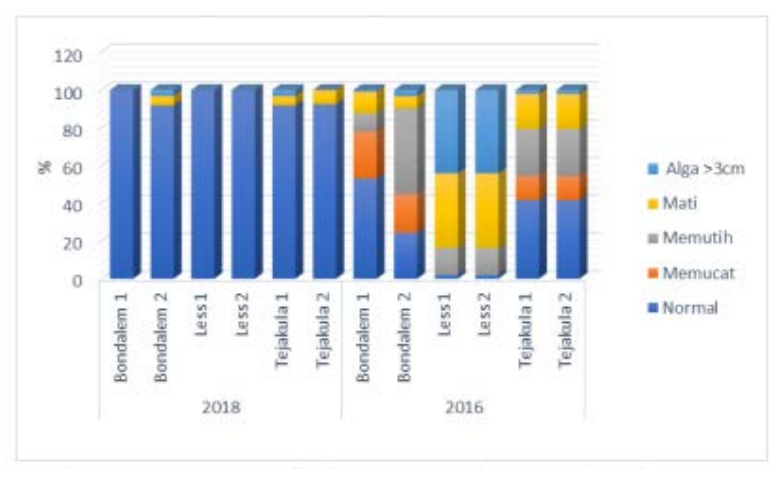

Gambar 4. Persentase kondisi karang keras tahun 2018 dan tahun 2016 
Tabel 2. Sebaran ukuran kerapu yang ditemukan di perairan Tejakula

\begin{tabular}{|c|c|c|c|c|c|c|}
\hline $\begin{array}{l}\text { Ukuran } \\
\text { Kerapu }\end{array}$ & $\begin{array}{c}\text { Bondalem } \\
1\end{array}$ & $\begin{array}{c}\text { Bondalem } \\
2\end{array}$ & $\begin{array}{c}\text { Less } \\
1\end{array}$ & $\begin{array}{l}\text { Less } \\
2\end{array}$ & $\begin{array}{c}\text { Tejakula } \\
1\end{array}$ & $\begin{array}{c}\text { Tejakula } \\
2\end{array}$ \\
\hline $30-40 \mathrm{~cm}$ & 5 & 2 & 0 & 1 & 0 & 0 \\
\hline $40-50 \mathrm{~cm}$ & 0 & 0 & 0 & 0 & 0 & 0 \\
\hline $50-60 \mathrm{~cm}$ & 0 & 0 & 0 & 0 & 0 & 0 \\
\hline$>60 \mathrm{~cm}$ & 0 & 0 & 0 & 0 & 0 & 0 \\
\hline
\end{tabular}

Tabel 3. Makrozobenthos indikator terumbu

\begin{tabular}{lcccccc}
\multicolumn{1}{c}{ karang } & & & & & & \\
\hline $\begin{array}{l}\text { Makrozoobenthos } \\
\text { indikator }\end{array}$ & B1 & B2 & T1 & T2 & L1 & L2 \\
\hline Banded coral shrimp & 0 & 1 & 0 & 0 & 3 & 2 \\
Diadema urchin & 0 & 5 & 0 & 0 & 6 & 5 \\
Pencil urchin & 0 & 0 & 0 & 0 & 0 & 0 \\
Collector urchin & 0 & 0 & 0 & 0 & 0 & 1 \\
Sea cucumber & 4 & 0 & 0 & 0 & 0 & 0 \\
Crown-of-thorns & 0 & 0 & 0 & 0 & 0 & 0 \\
Triton & 0 & 0 & 0 & 0 & 0 & 0 \\
Lobster & 0 & 0 & 0 & 0 & 0 & 0 \\
Giant clam & 0 & 0 & 0 & 5 & 4 & 5 \\
\hline
\end{tabular}

Makrozoobenthos yang didapatkan pada penelitian ini dapat dilihat pada table. Dari tabel terlihat Banded coral shrimp dan Diadema urchin ditemukan pada wilayah perairan Bondalem dan Less. Untuk indikator makrozoobenthos ditunjukkan pada table 3 .

Fenomena pemutihan karang pada tahun 2016 merupakan salah satu akibat dari kehilangan hewan karang yang disebabkan adanya tekanan yang terjadi pada lingkungannya yaitu peningkatan suhu yang lama. Reefcheck. co.id (2017) melaporkan daerah Tejakula menjadi salah satu daerah yang terkena dampak pemutihan karang, yaitu sebesar $24-46 \%$ dan beberapa sudah mengalami kematian yaitu sebesar 6-39.5\%. Perubahan terjadi pada tahun 2018, kondisi terumbu karang mengalami perbaikan. Pada tahun 2018 ini terumbu karang diperairan Tejakula sudah normal dengan persentase $92-100 \%$, jumlah terumbu karang yang mati berkurang menjadi $5-7.5 \%$ dan jumlah alga yang menutupi berkurang menjadi 3.125\%.

Kondisi terumbu karang yang sudah mulai pulih membuat ikan karang sudah banyak ditemukan. Terumbu karang dan ikan karang mempunyai kaitan yang sangat erat. Dalam

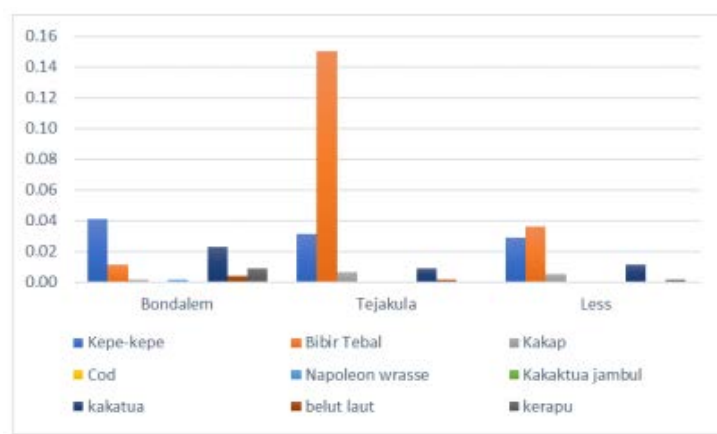

Gambar 5. Kelimpahan ikan di perairan kecamatan Tejakula

proses ko-evolusi, ikan karang tumbuh dan berkembang seiring dengan berkembangnya terumbu karang sebagai habitatnya. Ikan karang selalu merespon terhadap perubahan dalam ekosistem terumbu karang demikian juga sebaliknya, dimana terumbu karang dipengaruhi oleh perkembangan populasi ikan karang (Muttaqin, et al., 2017).

Ikan karang kepe-kepe dari family Chaetodontidae yang merupakan pemakan hewan karang dan beberapa merupakan ikan herbivore yang menjadi indikator kesehatan terumbu karang. Terumbu karang di perairan Tejakula ini sedang mengalami recovery akibat pemutihan karang yang terjadi pada tahun 2016, hal ini terlihat dari jumlah ikan kepekepe yang ditemukan sudah cukup banyak. Keberadaan ikan herbivora dan makrozoobenthos herbivora seperti Diadema urchin tersebut membantu mengurangi jumlah alga yang menutupi. Sedangkan keberadaan ikan pemakan terumbu karang dan ikan predator memperlihatkan bahwa sistem ekologi yang ada di terumbu karang tersebut hampir kembali normal.

Terumbu karang yang sudah mengalami recovery tersebut akan membuat ikan ekonomis penting seperti kakap dan kerapu sudah dapat ditemukan. Hal tersebut akan membuat stok ikan karang juga akan mengalami pemulihan, karena selama tahun 2015-2016 dari hasil wawancara dengan nelayan di kecamatan Tejakula, ikan karang mengalami penurunan dan nelayan harus mencari ikan lebih jauh dari sebelumnya.

\section{SIMPULAN DAN REKOMENDASI}

Dari hasil yang didapatkan, jenis terumbu karang yang banyak menutupi perairan Tejakula adalah Acropora Branching. Hal tersebut di- 
mungkinkan bahwa terumbu karang tersebut adalah terumbu karang yang baru muncul. Selain itu, ikan yang terdapat didaerah Tejakula adalah ikan herbivore, walaupun ada ikan karnivora, ukurannya masih kecil, maksimal < $30 \mathrm{~cm}$.

Pada tahapan berikutnya saya akan melihat bagaimanakah status ekosistem terumbu karang di perairan Tejakula ini, apakah mengalami peningkatan ataukah penurunan. Semua data akan diambil pada daerah yang sama ditambah dengan peta sebaran bentuk pertumbuhan terumbu karang di daerah Tejaku-

\section{DAFTAR PUSTAKA}

Hoegh-Guldberg O,lones R. 1999. Photoinhibition and photoprotection in symbiotic dinoflagellates from reef-building corals. Mar Ecol Progr Ser 183:73-86.

Jones R, Hoegh-Guldberg 0, Larkum AWL, Schreiber U. 1998. Temperature induced bleaching of corals begins with impairment of dark metabolism in zooxanthellae. Plant Cell Environ 21:1219-1230.

Mumby, P.J, A. Hastings, H.J. Edwards. 2007. Thresholds and the resilience of Caribbean coral reefs. Nature, vol. 450. 1 November 2007.

Muttaqin, E. M.Mukhlis K, S. Haryadi, S. Pardede, S. Tarigan, S. Campbell. 2014. Dampak Pemutihan Karang Terhadap Ekosistem Terumbu Karang Pada tahun 2010 di Perairan Utara Aceh. Jurnal Teknologi Perikanan dan Kelautan Vol. 5 No. 1 Mei 2014. Hal. 15- 21. la. Apabila terjadi peningkatan dalam semua point penilaian tersebut, ekosistem terumbu karang di daerah Tejakula akan memiliki tingkat kesehatan yang tinggi terhadap ancaman yang akan terjadi.

\section{UCAPAN TERIMA KASIH}

Terimakasih kepada keluarga besar Baruna Scientific Diving Club (BASIC) Udayana yang telah membantu saya dalam pengambilan data penelitian.

Rani, C. 2001. Ulasan Pemutihan Karang: Pengaruhnya Terhadap Komunitas Terumbu Karang. Jurnal Hayati. Vol.8 No.3. Hal. 86-90.

Reefcheck Indonesia. 2017. Summary data bleaching tahun 2016 (Tidak dipublikasikan)

Strong. A.E, G. Liu, C.M. Eakin, T.R.L. Christensen, W.J. Skirving, D.K. Gledhill, S.F. Heron, J. A. Morgan. 2008. Implications for Our Coral Reefs in a Changing Climate over the Next Few Decades -- Hints from the past 22 years. Proceeding of the 11th International Coral Reef Symposium, Ft. Lauderdale, Florida session number 25. 